\title{
DR. KLAUS MENZINGER, President of the IALL
}

Dr. Klaus Menzinger, President of the International Association Law Libraries, died all of a sudden on April 22, 1986, two months bef his term of office would have ended. Half a year earlier we had celebra his fiftieth birthday.

This Journal has already briefly reported the untimely death of $t$ active and prominent member of the Association. The feeling of $w$ l we have lost with Dr. Menzinger, however, is still there. It grows er stronger, the more his contributions to law, to librarianship and international cooperation both as an administrator and scholar co into focus.

He has achieved much in the relatively short span of his life a we owe him much.

Dr. Menzinger, the youngest of three brothers, was born on Septeml 27, 1935, in the southwest corner of Germany. Significantly he beg his university studies in the field of philosophy before he eventua turned to law. The philosophical approach never deserted him. Havi acquired all the necessary law degrees he considered for a moment go into private practice. But he decided to stay within the law libr: service of the University of Freiburg where he had already served smaller functions before.

He planned his career there and a career it was. He eventually ro in 1979, to the rank of Academic Director and head of the law libr: (the Juristisches Seminar). In this responsible position, conferred up him in a difficult time of transition in the German university syste he moulded, despite conflicting interests and internal strife, the instituti into the central law library of Freiburg university, generally recogniz as one of the best in the whole country.

With this solid professional background Dr. Menzinger engag himself in the international cooperation among law librarians and th institutions.

Being part of the Freiburg university law library scene, which $\mathrm{r}$ always been internationally minded, he became very early aware of $t$ necessity of international exchange among the members of the professic And in this field again, he started to work, where he was needed, a served in a great number of advisory functions. Later he became Edi1 of the International Journal of Law Libraries. Under his guidance $t$ journal made considerable progress and continued to become a usef research tool. Later he became member of the IALL Board of Directo in 1980 he was elected secretary and in 1983 he rose to the highest positi of the Association when he was elected its President. 
In this capacity Dr. Menzinger has done much more than to merely administer the Association. It was his strong conviction, that IALL can only live up to the expectations of its members, if the concomitant functions, honours and burdens are equally distributed on many shoulders in many countries. He was an eager internationalist-always trying to engage more people and to spur the old ones. That made him travel into all parts of the world, organize or attend work shops, regional meetings, conferences and symposia.

In 1984, on the occasion of the 25 th anniversary of the International Association of Law Libraries, he organized the IALL conference in his home town of Freiburg. It was an event unforgotten by those who attended it. With this congress Dr. Menzinger demonstrated both the idea of international cooperation among law librarians and the charm of his beloved Freiburg, capital of the Black Forest.

Both his professional work and his far-reaching interests inspired Dr. Menzinger to do additional research and publish his achievements beyond the realm of his daily work. His book on particular problems of German bankruptcy law provides deep insights into the German legal system and its rules. His four volume "Deutsche Rechtsbibliographie 1982-1985" has become an indispensable international research tool. The number of articles which he contributed to German and foreign periodicals on law and library related materials has yet to be counted.

Dr. Klaus Menzinger leaves his wife and three sons behind. Together with them we mourn the loss of a remarkable man, an internationally respected law librarian and a good friend.

Dr. Gerhard J. Dahlmanns 